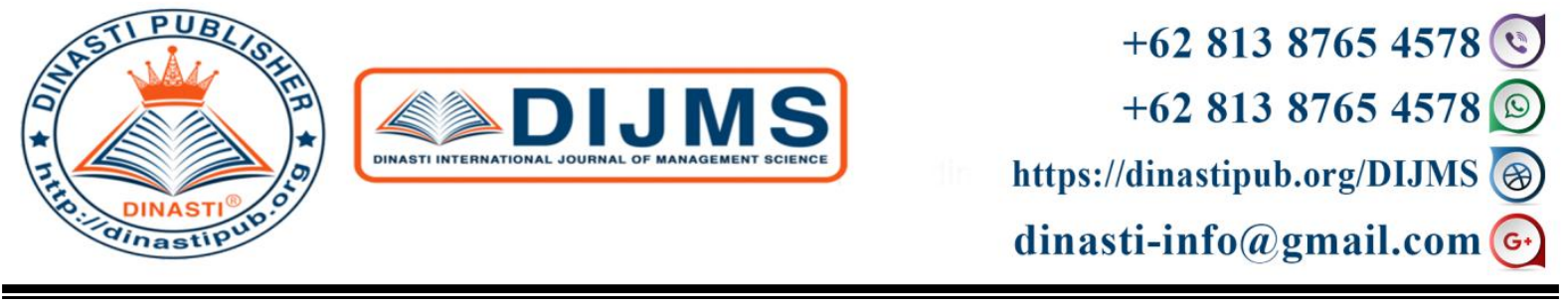

\title{
THE EFFECT OF JOB SATISFACTION AND ORGANIZATIONAL COMMITMENT ON TEACHER TURNOVER INTENTION IN X INSTITUTION IN PALEMBANG
}

\author{
Iwan Suwantono Kusuma ${ }^{1}$, Lin Yan Syah ${ }^{2^{*}}$ \\ 1) Management Magister Bina Darma University, Palembang, Indonesia \\ ${ }^{2)}$ Economic and Business Faculty, Bina Darma University, Palembang, Indonesia
}

\begin{tabular}{|l|l|}
\hline ARTICLE INFORMATION & $\begin{array}{l}\text { Abstract: The purpose of this researches to gain proper } \\
\text { Received: } 19^{\text {th }} \text { April } 2020 \\
\text { kevised: } 30^{\text {th }} \text { April } 2020 \\
\text { Issued: } 08^{\text {th }} \text { May } 2020\end{array}$ \\
$\begin{array}{l}\text { and Organizational Commitment on Turnover intention in } \\
\text { X Institution of Palembang. This study used a survey } \\
\text { which studied data from sample taken from the distribution } \\
\text { of questionnaires to 92 respondents with details of } 30 \\
\text { people as test sample and 62 respondents as research } \\
\text { sample. Data were analyzed using structural equation } \\
\text { modeling (SEM) methods. The results showed that the t- } \\
\text { value for job satisfaction is 4.79 (> 1.96) resulted in } \\
\text { negative which means there are significant effect of job } \\
\text { satisfaction on turnover intense. T-value for organizational } \\
\text { commitment is 3.19 (> 1.96) resulted in negative which } \\
\text { means there are significant effect of organizational } \\
\text { linyansyah@binadarma.ac.id } \\
\text { commitment on turnover intense. }\end{array}$ \\
$\begin{array}{l}\text { Keywords: Job Satisfaction, Organizational Commitment, } \\
\text { Turnover Intention }\end{array}$ \\
\hline
\end{tabular}

\section{INTRODUCTION}

National education is developed in the context of educating people in the life of the nation in order to become human beings who believe in God Almighty (UU Sistem Pendidikan Nasional, 2003). To support the realization of the national education goals, the school as a formal educational institution has a very important role in creating quality human resources, both in science and the character of students. Therefore, a management system is needed to run an educational institution.

According to Ricky W. Griffin (2013) management is a series of activities, including the process of planning and decision making, organizing, and controlling any available resources to achieve the goals that have been determined effectively and efficiently. Effective means that goals can be achieved in accordance with existing plans, and efficient means implemented correctly and organized in accordance with a predetermined schedule. 
One important thing in achieving these goals is the need for quality human resources. According to Mathis \& Jackson (2010), human resource management is a system created so that the capabilities of every human being can be maximized properly in order to achieve the expected goals. One of the most important components in realizing quality education is the presence of educators who have sufficient quality.

One of the efforts made by each school to maintain the quality of education is to reduce the level of teacher turnover. According to Mathis and Jackson (in Yulia Safitri \& Nursalim, 2013), turnover is a condition where an employee decides to leave an organization and must be replaced by someone else. The high level of turnover will have a major influence on the running of an organization (Langton, Robbins, \& Judge, 2015).

Teacher turnover can be caused by several factors. According to Chen et al (2006) in (Zahra, 2016), there are two factors that are most influential in determining employee turnover, including job satisfaction and organizational commitment. Research conducted by Andini (2010), Utami \& Bonussyeani (2009), shows that job satisfaction and organizational commitment have a great influence on employee turnover. In contrast to the research conducted by Mandeno (2017), Tnay, Othman, Siong, \& Lim (2013), and Yulia Safitri \& Nursalim (2013) where job satisfaction affects turnover intention, while organizational commitment does not affect employee turnover levels.

Based on field observations, at the age of 10 years the number of students in $\mathrm{X}$ Institution Palembang over the past three years shows an increase. The 2016-2017 school year the number of 628 students, in 2017-2018 increased to 690 people, and increased again in 2018-2019 with a total of 745 students.

$\mathrm{X}$ Institution also has a great concern in educating students so that they not only have high academic ability, but also have a good personality that is useful for the development of students in the future. This is shown by the school's vision of "Manifesting the Beauty of Mankind". One way that the school does is to routinely provide motivation to all employees.

The teacher turnover intention at this school is also quite high. The number of teachers who have dropped out over the past 3 years can be seen in the table below:

\section{Tabel 1.}

The Number of Teachers Dropped Out in 2016-2018

\begin{tabular}{|l|c|c|c|}
\hline \multirow{2}{*}{} & \multicolumn{3}{|c|}{ Years } \\
\cline { 2 - 4 } & $\mathbf{2 0 1 6}$ & $\mathbf{2 0 1 7}$ & $\mathbf{2 0 1 8}$ \\
\hline Total Teachers (People) & 65 & 82 & 92 \\
\hline Total outgoing teachers (people) & 12 & 7 & 21 \\
\hline Percentage of teachers out (\%) & 18,46 & 8,53 & 22,82 \\
\hline
\end{tabular}

From the above data, the total number of teachers dropped out during the last 3 years reached $49.81 \%$. According to Suryani, Kuncara, \& Nurjanah (2014) the percentage of employee turnover above $10 \%$ is classified as very high in an organization. This is a big problem for $\mathrm{X}$ Institution because many teachers who are considered capable of carrying out their tasks well are also included in the data of the exiting teachers. 
This makes the writer interested in conducting further research on the The Effect of Job Satisfaction and Organizational Commitment on Teacher Turnover Intention in $\mathrm{X}$ Institution In Palembang.

\section{LITERATURE REVIEW}

\section{Job Satisfaction}

According to Hasibuan (2001) Job satisfaction is a good emotional attitude at work and loves the work they have. This attitude can be seen through attitudes at work and achievements during work. Job satisfaction is not only obtained from work, but also obtained in pleasure at work.

According to Langton et al. (2015),, job satisfaction is a positive feeling about work generated based on an evaluation of its characteristics.

According to Levi (2002), there are several aspects that exist in job satisfaction, namely:

1. The work itself (work it self)

Difficult whether or not a job can affect job satisfaction. In addition, a person's feelings for his expertise needed to do the job, will increase or reduce job satisfaction.

2. Supervisor (Supervision)

A good boss is someone who is able to appreciate the work of his subordinates. With a boss who respects his subordinates will affect the level of employee job satisfaction.

3. Workers

Is a factor related to friends in the same work environment.

4. Promotion (Promotion)

Are factors associated with opportunities for career advancement during work.

5. Salary / Wages (Pay)

Is an important fulfillment factor of life needs for employees.

\section{Organizational Commitment}

According to Luthans (2011) organizational commitment is defined as a strong desire from employees to remain part of an organization, willingness to exert their abilities for the organization, and to be sure and believe in organizational goals.

Colquitt, LePine, \& Wesson (2017) say that organizational commitment focuses on why individuals and groups in an organization act like they do. According to Mayer and Allen (1990) in Islamy (2016), said that there are 3 basic dimensions of organizational commitment, namely:

1. Affective commitment: refers to the emotional connection of members to the organization and beliefs in its values.

2. Normative commitment: refers to the obligation of employees to remain in the organization due to certain pressures.

3. Ongoing commitment: refers to the desire of employees to stay in the organization related to the calculation of economic value if it survives rather than leaving the organization. 
According to Mowday, Porter, \& Steers (1982), organizational commitment is the level of a person's identification of a particular organization. These commitments are grouped into 3 factors:

1. Strong belief and acceptance of organizational goals;

2. The desire to exert effort in carrying out the interests of the organization; and

3. A strong desire to survive in the organization.

\section{Turnover Intention}

According to Robbins \& Mary Coulter (2012), turnover is the termination of work performed by employees either voluntarily or not voluntarily. Turnover can be in the form of resignation, leaving an organizational unit, dismissal or the inability of members of the organization to continue work.

According to Mathis \& Jackson (2010) employee turnover is classified into several types, namely:

1. Based on employee willingness, turnover is divided into two types, namely voluntary turnover and involuntary turnover:

(a) Voluntary turnover. Employees leave an organization of their own free will. Voluntary turnover can be caused by several factors, such as career path, salary earned, supervision, personal / family reasons and others.

(b) Voluntary turnover. Turnover is involuntary caused by organizational policies, regulations and performance standards that are not able to be met by employees, such as poor performance, violations of work regulations, and so on.

2. Based on the functional level, turnover is divided into two types, namely functional turnover and dysfunctional turnover:

(a) Functional turnover. Caused because employees have low performance, less reliable, or annoying colleagues. This causes employees to leave the organization.

(b) dysfunctional turnover. Are employees who have an important role and have high performance, but leave the organization at a critical time.

3. Based on the form of control, turnover is divided into two types, namely turnover that can be controlled and turnover that cannot be controlled:

(a) Controllable turnover. Appears because of factors that are influenced by employers. In controlled turnovers, organizations are better able to manage employees if they are able to solve employee problems that can cause turnover.

(b) Uncontrollable turnover. Appears for reasons outside the influence of the employer. If the dismissal from outside cannot be controlled by the organization, such as the transfer of employees from a geographical area, the employee decides to stay in an area far from the workplace due to family reasons, the wife is in charge of household affairs in other geographical areas and so forth. 


\section{RESEARCH METHODS}

\section{Research Types, Populations, and Samples}

This research was conducted at the X Institution Palembang. The population in this study were 92 teachers of $X$ Institution. The sample used was the entire population of 92 people with 30 details as a trial sample and 62 people as a research sample.

This research uses quantitative research methods. Data collection was carried out using a closed questionnaire. Each item is provided with an alternative answer using a Likert scale. The collected data is then processed statistically using the structural equation model (SEM) which is processed using the Lisrel 7.8 program.

\section{Operational Variables}

In this study, research variables measured as follows:

a. The independent variable $(\mathrm{X})$ is job satisfaction and organizational commitment.

b. The dependent variable $(\mathrm{Y})$ is the turnover intention.

\section{FINDINGS AND DISCUSSION}

\section{Descriptive Analysis}

Before analyzing the structural model, the researcher first tests the suitability of the measurement model to test the validity and reliability of the indicators forming latent variables. This validity test is carried out with the CFA first order test with one variable, and tested on the variables of job satisfaction, organizational commitment and turnover intention.

\section{Goodness of Fit Test}

Tabel 2. Goodness of Fit Full Result

\begin{tabular}{|c|c|c|c|c|}
\hline \multicolumn{2}{|c|}{ GOODNESS-OF-FIT INDEX } & \multirow{2}{*}{$\begin{array}{l}\text { NILAI } \\
\text { BATAS }\end{array}$} & \multirow[b]{2}{*}{ NILAI } & \multirow[b]{2}{*}{ Kecocokan Model } \\
\hline NO & $\begin{array}{l}\text { Absolute/predictive fit } \\
\text { indices }\end{array}$ & & & \\
\hline 1 & chi square & kecil & 33,95 & Model fit \\
\hline 2 & $\begin{array}{l}\text { Significance probability } \\
(\mathrm{P}=\text { Value })\end{array}$ & $\geq 0,05$ & 0,61 & Model fit \\
\hline 3 & $\mathrm{X}^{2} / \mathrm{DF}$ & $<2$ atau 3 & 0,92 & Model fit \\
\hline 4 & RMR & $\leq 0,10$ & 0,17 & Model not fit \\
\hline 5 & SRMR & $\leq 0,08$ & 0,073 & Model fit \\
\hline 6 & RMSEA & $\leq 0,08$ & 0,0 & Model fit \\
\hline 7 & GFI & $>0,90$ & 0,91 & Model fit \\
\hline \multirow[t]{2}{*}{8} & AGFI & $>0,90$ & 0,84 & Model not fit \\
\hline & Comparative fit indices & & & \\
\hline 9 & NFI & $>0,90$ & 0,95 & Model fit \\
\hline 10 & IFI & $>0,90$ & 1,00 & Model fit \\
\hline \multirow[t]{2}{*}{11} & CFI & $>0,90$ & 1,00 & Model fit \\
\hline & Parsimonious fit indices & & & \\
\hline 12 & PNFI & $>0,90$ & 0,64 & Model not fit \\
\hline 13 & PGFI & $>0,90$ & 0,51 & Model not fit \\
\hline
\end{tabular}




\section{AIC}

Based on table 1.2 we can see that there are only four values that do not match the value of the Goodness of Fit indicator, consists of RMR 0.17 (should be $\leq 0.10$ ), AGFI 0.84 (should be> 0.90), PNFI 0.64 (should be> 0.90), and PGFI 0.51 (should be>0.90). According to Malhotra (2010) in Gunarto (2018), if the model meets one of each of the absolute good sizes (GFI or AGFI), absolute size is bad (Chi-square, RMSR, SRMR, or RMSEA), and comparative size ( NFI, NNFI, CFI, TLI, or RNI), then the model can be said to be fit. Based on table 1.2 the model has fulfilled one size each so that the model is Fit.

\section{Model Interpretation}

Based on the output of the Lisrel program, the following structural equation is obtained:

Turnover $=-0.66 *$ Satisfaction $-0.37 *$ Commitment, Errorvar. $=0.12, \mathrm{R}^{2}=0.87$
$(0.14)$
$(0.11)$
1.04

From the above equation it can be seen that job satisfaction affects the turnover level of -0.66 meaning that each addition of one unit of job satisfaction will reduce the turnover intention by 0.66 assuming that the other variables are fixed, organizational commitment influences the turnover level of $-0,37$ means that every addition of one organizational commitment unit will reduce the turnover intention by 0.37 assuming that the other variables are fixed.

$\mathrm{R} 2$ values indicate a score of 0.87 . R-square value (R2) serves to determine the effect of independent variables on the dependent variable. The value of $\mathrm{R} 2$ ranges from 0 to 1. The higher the value of $\mathrm{R} 2$, the greater the effect of the independent variable on the dependent variable. The smaller the value of $\mathrm{R} 2$ means the independent variable has no effect at all on the dependent variable.

\section{Hypothesis test}

Hypothesis 1

Ho: Job satisfaction has no effect on turnover intention

H1: Job satisfaction influences turnover intention

Based on the structural equation above it can be seen that the calculation results obtained by the t-value of negative 4.79>1.96, so that Ho is rejected. This means that there is a negative and significant effect on job satisfaction on turnover intention.

\section{Hypothesis 2}

Ho: Organizational commitment has no effect on turnover intention H1: Organizational commitment influences turnover intention

Based on the structural equation above, it can be seen that the calculation results obtained a t-value of negative 3.19>1.96, so that Ho is rejected. This means that there is a negative and significant effect on job satisfaction on turnover intention.

Based on the structural equation above it can be seen that the calculation results obtained by the value of $\mathrm{R} 2=0.87$ close to 1 . This means that $87 \%$ turnover intention was effected by job satisfaction and organizational commitment. 


\section{CONCLUSION AND SUGESTION \\ Conclusion}

There is a negative and significant influence on job satisfaction on the teacher turnover intention at the $\mathrm{X}$ Institution Palembang. This is indicated by the t-value of negative 4.79> 1.96. So, if teachers have high job satisfaction, then the tendency of teachers to leave the organization is lower.

There is a negative and significant influence on organizational commitment to the level of teacher turnover at the X Institution Palembang. This is indicated from the t-value of negative 3.19>1.96. So, if teachers have high organizational commitment, the tendency of teachers to leave the organization is lower.

\section{Suggestion}

Some suggestions to be conveyed and given:

1. For teachers should make salary as motivation in work. As performance improves, salaries will increase.

2. For the Foundation can pay more attention to employee job satisfaction, especially salaries given to teachers. It aims to increase the commitment of teachers at work and reduce the level of teacher turnover.

3. For further research, further researchers can expand the object of research that is not only limited to the X Institution Palembang, so that researchers can obtain more samples than this study.

4. For further research can explore more information than just a questionnaire, so that they can better understand the real situation and not subjective with the questionnaire. This can be done with a little interview with the respondent concerned. So, you should do a little modification of data collection techniques, so that researchers can get other information outside the statements in the questionnaire.

\section{REFERENCE}

Andini, R. (2010). Analisis Pengaruh Kepuasan Gaji, Kepuasan Kerja, Komitmen Organisasional Terhadap Turnover Intention. Jurnal Dinamika Sains, 1.

Colquitt, J. A., LePine, J. A., \& Wesson, M. J. (2017). Organizational Behavior. In PPI Pulp and Paper International (5th ed.). Mc Graw Hill Education.

Gunarto, M. (2018). Analisis Statistik dengan Model Persamaan Struktural (SEM): Teoritis dan Praktis (1st ed.). Bandung: Alfabeta.

Hasibuan, M. (2001). Manajemen Sumber Daya Manusia. Jakarta: PT. Bumi Aksara.

Islamy, F. J. (2016). Pengaruh Komitmen Afektif, Komitmen Normatif dan Komitmen Berkelanjutan Terhadap Turnover Intention Pada Dosen Tetp STIE INABA Bandung. JURNAL INDONESIA MEMBANGUN, 15(2), 164-181.

Langton, N., Robbins, S. P., \& Judge, T. A. (2015). Organizational behaviour. In Psychology and People: A Tutorial Text (7th ed.). https://doi.org/10.1007/978-1-349-16909-2_19 
Levi. (2002). Faktor-Faktor Yang Mempengaruhi Kepuasan Kerja. Retrieved December 15, 2019, from http://id.wikipedia.org/wiki/Kepuasan_Kerja

Luthans, F. (2011). Organizational Behavior. In Hospital Administration (12th ed.). https://doi.org/10.5005/jp/books/10358_23

Mandeno, E. I. (2017). Pengaruh Kepuasan Kerja dan Komitmen Organisasi Terhadap Turnover Intention. Skripsi Fakultas Ekonomi Universitas Sanata Dharma Yogyakarta.

Mathis, R. L., \& Jackson, J. H. (2010). Human Resource Management \& Entrepreneurship Human Resource Management \& Entrepreneurship (13th ed.). South-Western College Pub.

Mowday, R. T., Porter, L. W., \& Steers, R. M. (1982). Organizational and Occupational Psychology. In Assessment Centers and Managerial Performance. https://doi.org/10.1016/b978-0-12-690620-2.50001-5

Ricky W. Griffin. (2013). Management (11th ed.). USA: Cengage Learning.

Robbins, S. P., \& Mary Coulter. (2012). Management. In Journal of Chemical Information and Modeling (11th ed., Vol. 11). https://doi.org/10.1017/CBO9781107415324.004

Suryani, A., Kuncara, H., \& Nurjanah, S. (2014). Pengaruh Kepuasan Kerja Terhadap Intensi Turnover Pada Guru Di Yayasan Pgri Cipayung Jakarta Timur Ayu Suryani. Jurnal Pendidikan Ekonomi Dan Bisnis (JPEB), 2(1). https://doi.org/10.21009/jpeb.002.1.4

Tnay, E., Othman, A. E. A., Siong, H. C., \& Lim, S. L. O. (2013). The Influences of Job Satisfaction and Organizational Commitment on Turnover Intention. Procedia - Social and Behavioral Sciences, 97, 201-208. https://doi.org/10.1016/j.sbspro.2013.10.223

Utami, I., \& Bonussyeani, N. E. S. (2009). Pengaruh Job Insecurity, Kepuasan Kerja, Dan Komitmen Organisasional Terhadap Keinginan Berpindah Kerja. Jurnal Akuntansi Dan Keuangan Indonesia, 6(1), 117-139. https://doi.org/10.21002/jaki.2009.06

UU Sistem Pendidikan Nasional. (2003). Sistem pendidikan nasional. Bandung: Citra Umbara.

Yulia Safitri, R., \& Nursalim, M. (2013). Hubungan Antara Kepuasan Kerja Dan Komitmen Organisasi Dengan Intensi Turnover Pada Guru. Character: Jurnal Penelitian Psikologi., 1(2).

Zahra, A. (2016). Pengaruh Kepuasan Kerja dan Komitmen Organisasional Terhadap Turnover Intention Pada PT. Nusantara Media Baliwangi. Retrieved from http://library.binus.ac.id/Collections/ethesis_detail/2016-1-00054-MN 